\title{
THE USAGE OF TESTS OF ENDURANCE DURING THE WORK WITH THE STUDENTS OF FACULTY OF SECURITY SCIENCES
}

\author{
Darko Paspalj ${ }^{1}$ and Milan Gužvica ${ }^{1}$ \\ ${ }^{1}$ Faculty of Security Sciencess, University of Banja Luka, Bosnia and Herzegovina
}

Original scientific paper

\section{Summary}

The research was conducted on a sample of 27 male students of the first year of the Faculty of Security Studies in order to determine the value of the functional capabilities of the students of the Faculty of Security Sciences achieved during the Cooper test and the Beep test, in order to consider the possibility of applying the Beep test in the process of assessing the functional capabilities of students when conducting the selection process for admission to the faculty. Using the appropriate statistical procedure, it was found that there is no statistically significant connection of variables for the evaluation of morphological characteristics with the results achieved on the Beep test and the Cooper test, as well as that there is no statistically significant connection of variables for the assessment of morphological characteristics with the obtained results of maximum oxygen consumption on the Beep test and Cooper test. Also, it was found that there is no a difference in maximum oxygen consumption between the tests that were applied. Considering variability of the load that is characteristic of the Beep test and the similarities with specific activities characteristic for the performance of elements and their connections in the teaching process of the SFO (Special Physical Education Program), the authors suggest that the Beep test should be included in the tests that are used to determine the functional capabilities of the candidates when conducting the selection process for admission candidates for education at the Faculty of Security Sciences. The gathered information can also be used to make and optimize the plan and program of the SFO, as well as to create homogeneous groups in order to achieve efficient learning outcomes.

Keywords: students, Cooper test, Beep test, selection

\section{INTRODUCTION}

The term "teaching" in Special Physical Education Program (later in the text referred to as SFO) represents the process of planned and systematic transfer and adoption of special thematic areas adjusted to students of the Faculty of Security Sciences that are relevant for the future performance of their professional duties and responsibilities, and it includes many components. The basic ones are: acquiring knowledge, forming skills, forming habits and increasing their knowledge, skills and habits. The performance and practical use of techniques from the Special Physical Education Program (SFO) is conditioned by both high technical and motor abilities and functional and mental abilities, as well as by appropriate anthropometric predispositions. In order to realize the teaching process 
and assure the active participation of the students in the program of SFO, in addition to the motor skills such as strength, speed, flexibility, coordination, agility, precision and balance, very important skill is also endurance. Endurance is the ability of an individual to maintain his working ability over a longer period of time, so each individual needs to develop an optimal level of functional abilities, where mixed aerobic-anaerobic energy processes dominate, and they are characterized by simple and complex movements. Pelemis et al. (2011) state that the physiological basis of physical working capacity is the functional ability of the organism to increase the level of metabolic processes in accordance with the demands of the physical effort that the organism is exposed to, and metabolic processes mean the transformation of chemical energy into muscular contraction. According to Milosevic, the level of development of functional characteristics determines the speed of force development, the speed of movement and long-term operation without visible signs of fatigue, and without significantly reducing its efficiency, and it depends on the energy reserves and the functional quality of the energy chain that ensures the supply of muscle with energy for the work from adenosyntrifosfat. (Milošević, M., \& Milošević, M. 2013). Vučić (2016) in his thesis states that aerobic ability represents the ability of an organism to produce, using aerobic metabolic processes (oxidative degradation of carbohydrates and free fatty acids), the energy necessary for physical work and is associated with activities in which all the necessary energy for muscle work is provided from oxidative metabolic processes. The size of the aerobic capacity depends of the functional state of all organic and metabolic systems involved in the transport of oxygen and the usage of it in making energy necessary for work. The basic physiological indicators of the aerobic functional abilities of the organism are the values of maximum oxygen consumption $\left(\mathrm{VO}_{2}\right.$ max) which implies the highest amount of oxygen the organism can spend in one minute (Matković \& Ružičić 2009), and they are expressed in absolute $(1 / \mathrm{min})$ or relative units $(\mathrm{ml} / \mathrm{kg} / \mathrm{min})$. Skinner \& McLellan (1980) state that oxygen consumption in the aerobic threshold achieves a stable value which is the same as the intensity of work from moderate physical activity, and then the concentration of lactic acid in the working muscle and blood above the resting level increases, but the balance between accumulation and decomposition of lactate is still possible, and then a stable state of oxygen consumption and a stable concentration of lactic acid in the blood occurs.

Limited number of lessons intended for learning and improving the planned SFO program requires a constant search for new resources and methods, which means a greater level of science and its implementation, both in the learning process and in the process of student development. The program of the SFO is characterized by polystructural acyclic movements, which makes it very complex and intense, since its performance requires the frequent use of phosphagenic sources of energy. The program requires the complete control of aggression and movement in static and dynamic conditions that are reflected in the level of performance of techniques that is achieved, such as movements, shocks, blocks, lugs, cleansing and throwing, in as short period of time as possible. Although most of the SFO program contents are taking place under anaerobic conditions (movements are performed in the shortest time unit), there is the possibility of performing such motor programs that require significantly more time, and, therefore, different conditions (aerobic-anaerobic) in which motor programs would be realized. Of course, this involves activity in which there is increased oxygen consumption and depends mostly on the energy capacity of the organism which should provide sufficient number of repetitions of specific motor programs. High level of energy capacities gives opportunity, not only for long-term work and accepting the specific motor programs from the SFO, but also the possibility to use them practically. That means that high intensity is required for the efficient realization, and the intensity may last even for a few minutes. This is especially noticeable in 
new and unforeseen situations, where it is necessary to reprogram the previously formed motor program, and that requires increased mental and physical activity. This is why a future security worker must achieve a high level of physical, technical, tactical, psychological and integral preparedness in performing his professional duty. Of course, this is a very difficult and complex task that takes the right amount of time in which the optimal number of repetitions of simple and complex situations is possible. Unfortunately, the optimum number of repetitions in the available training time, which would allow the automation of the elements of the technique and their connections, is simply not possible. It is considered that a high level of specific endurance would enable students to have more repetitions even in the limited training time, and that would significantly influence the acceptance of those motor programs. High level of all aspects of physiological abilities, as well as the high level of specific technical abilities, would enable future security workers to use the program from the SFO successfully. Blagojević, Dopsaj \& Vučković (2006), based on previous studies, state that it is necessary that the aerobic capabilities of police officers are developed at the level of maximum oxygen consumption between 48 and $50 \mathrm{ml} / \mathrm{kg} / \mathrm{min}$, in order to perform standard police work efficiently. The same authors (2016) state that police officers with a higher level of general endurance, i.e. with a higher level of development of the aerobic energy system have a statistically significant easier compensation of the stressful situation and, in situations of specific fatigue, they recover from stress faster. It is obvious that the physical abilities of individuals must be at the appropriate level in order to successfully perform security tasks, and this is one of the reasons why there is more and more attention to the selection of candidates enrolling at the faculty. Considering the fact that students of the Faculty of Security Sciences (FBN) were subjected to tests of motor and functional abilities when enrolling in school, it is possible to say that after selecting candidates, they belong to a homogeneous group, which is why the idea for research came out precisely from the need to examine the impact of morphological characteristics in estimation of functional abilities and value of maximum oxygen consumption $\left(\mathrm{VO}_{2} \mathrm{max}\right)$. Although it is known that the "actual" maximum oxygen consumption is best assessed in the laboratory, due to the high cost and impracticality of organizing it, the authors decided to evaluate functional abilities in field conditions. The assessment of aerobic abilities was based on the results of the maximum oxygen consumption achieved on the Cooper and Beep tests of the maximum multistage loading by 20 meters return run, which is also the subject of this research. During the selection of the candidates who wanted to enroll at the Faculty of Security Sciences, when assessing the functional, metabolic processes, a Cooper test is planned, since it implies continuity (by its time determination), while the Beep test of the maximum multistage loading by 20 meters return run is characterized by discontinuity, i.e. by the acceleration and deceleration of movement, which also characterizes the performance of motor programs from the SFO.

The research was conducted in order to determine the possibility of predicting the values of functional capabilities achieved during the performance of the Cooper test, based on the values of the functional capabilities achieved during the performance of the Beep test, for the purpose of considering the possibility of using the Beep test of the maximum multistage loading by 20 meters return run in the selection of candidates and assessing functional abilities during the implementation of the selection process for admission to education. 


\section{METHODS}

The research lasted for seven days, during which the data was collected and classificated, and also statisticaly analysed. The sample of examinees consisted of 27 male students of the first year of the Faculty of Security Studies in Banja Luka, age $19 \pm 0.6$ years, which were clinically healthy, without visible physical defects or morphological aberrations. The basic anthropomorphological indicators of the tested sample were: TV $183.11 \pm 5.12 \mathrm{~cm}$, TM $81.25 \pm$ $8.02 \mathrm{~kg}$ and ITM $22.35 \pm 1.96$. In order to determine the starting point for the selection of candidates and the realization of the classes for students (in order to obtain data on their basic morphological predispositions) it was necessary to determine whether, on the basis of somatic status, the results of the tests of functional abilities can be predicted, in order to avoid any kind of discrimination of candidates and participants. To determine morphological characteristics, the following variables were analyzed: body mass (TM), body height (TV) and body mass index (ITM). Those variables were included because they are indications that there are some eating disorders that lead to obesity or malnutrition, which may affect motor abilities and performance of the tests (and on the tests). The morphological characteristics were determined the day before the first test was performed using an anthropometer by Martin (body height) and the Body Composition Analyzer of the brand Tanita, model BC - 418 (body weight and ITM). Variables which were used for determining the level of functional abilities of the examinees were tests for assessing the level of endurance: Cooper test and Beep test of the maximum multistage loading by 20 meters return run (who's authors are Leger \& Lambert 1982), since those are two field tests used for assessing the functional abilities and the tests that were most commonly used in the practice so far. Both tests were realised according to the standard procedure on the athletic track, during the time period of seven days, so the Cooper test was conducted on the first day, and after five days (during which the examinees were disengaged from mandatory physical activity) the Beep test was used. The estimate of the maximum oxygen consumption for the Cooper test was determined on the basis of the formula for estimating the maximum oxygen consumption (given by Sudarov in 2007), which is: $\mathrm{VO}_{2} \max (\mathrm{ml} / \mathrm{kg} / \mathrm{min})=($ Running distance $(\mathrm{m})-504.9) / 44.73$. The estimate of the maximum oxygen consumption for the Beep test was determined by adding the run-off level of the Beep test to the "beep calculator", which is calculated on the basis of the algorithm (Legel and Gadoury, 1989), where VO2 $\max (\mathrm{ml} / \mathrm{kg} / \mathrm{min})=18.043461+(0.3689295$ $\mathrm{x}$ TS $)+(-0.000349 \times$ TS $x$ TS $)$, and TS stands for the total number of intervals. Statistical evaluation of data was conducted on Pentium 4 PC, using the application statistical program SPSS (version 20.00). The basic measures of central tendency and measures of the dispersion of results were determined using the arithmetic mean (Mean) and standard deviation (Std. Deviation). In order to test the regularity of the data distribution, the Kolmogorov-Smirnov test was used, while correlation analysis was used to determine the correlation between variables of morphological characteristics and results, and the regression analysis was used for the prediction of results achieved in tests that were based on morphological characteristics. The correlation between the results of the Beep test and the Kuper test was determined by the correlation analysis. 


\section{RESULTS}

Table 1. Descriptive statistics of the Beep test and variables used for estimating morphological characteristics

\begin{tabular}{ccccccc}
\hline Variables & N & Min & Max & Mean & S D & KS test \\
\hline AVIT & 27 & 170,00 & 193,00 & 183,11 & 5,12 & 0,856 \\
ATET & 27 & 60,00 & 89,00 & 81,25 & 8,02 & 0,992 \\
ITM & 27 & 18,87 & 26,26 & 22,35 & 1,96 & 0,999 \\
VO 2 BEEP & 27 & 36,40 & 53,70 & 44,37 & 4,48 & 0,849 \\
BEEP & 27 & 980 & 2040 & 1453,33 & 276,68 & 0,903
\end{tabular}

Legend: N - number of examinees; Min. - minimal result; Max. - maximum result; Mean - arithmetic mean; Std. Deviation - standard deviation; KS (p) - value of probability of Kolmogorov - Smirnov test; AVIT - body height, ATET - body weight, ITM - body mass index, VO2 BEEP - maximum oxygen consumption achieved on the Beep test; BEEP - number of meters of running earned on the Beep test.

Table 1 shows the descriptive values of the variables used for estimating morphological characteristics and variables used for estimating the maximum oxygen consumption and the results of the number of meters running earned on the Beep test. It was determined that the distribution of the results was well grouped and that there were no significant deviations from the mean values of the results, which is also indicated by the value of the KS test. During the analysis of the differences between the minimum and maximum results, the highest ranking value was shown by the Beep test variable (BEEP), and the lowest value of the ranking is the maximum oxygen consumption of the Beep test $\left(\mathrm{VO}_{2} \mathrm{~B}\right)$. In the Beep test, the highest score achieved by the examinees was 2,040 meters and the least was 980 meters, with a range of 1,060 meters between the minimum and the maximum score. During the analysis of the maximum consumption of oxygen in the Beep test, it was discovered that the subjects achieved a maximum value of $53.70(\mathrm{ml} / \mathrm{kg} / \mathrm{min})$ and a minimum of $36.40(\mathrm{ml} / \mathrm{kg} / \mathrm{min})$, with a range of $17.3(\mathrm{ml} /$ $\mathrm{kg} / \mathrm{min})$.

Table 2. Regression analysis of $\mathrm{VO}_{2}$ max Beep test and variables used for estimation of morphological characteristics

\begin{tabular}{lcccc}
\hline Model & $\mathrm{R}$ & R Square & $\begin{array}{c}\text { Adjusted R } \\
\text { Square }\end{array}$ & Std. Error \\
\hline $\mathbf{1}$ &, $231^{\mathrm{a}}$ &, 053 &,- 070 & 4,64143 \\
\hline
\end{tabular}

a. Predictors (Constans) AVIT, ATET, ITM

b. Dependent variable $\mathrm{VO}_{2} \mathrm{BEEP}$ 
Table 3. Results of $\mathrm{VO}_{2} \max$ on the Beep test based on morphological characteristics

\begin{tabular}{rrrrrrr}
\multirow{2}{*}{ Model } & & \multicolumn{2}{c}{ Unstandardized Coefficients } & $\begin{array}{c}\text { Standardized } \\
\text { Coefficients }\end{array}$ & $\mathrm{t}$ & \multirow{2}{*}{ Sig. } \\
\cline { 3 - 5 } & & B & Std. Error & Beta & & \\
\cline { 3 - 6 } $\mathbf{1}$ & (Constant) & 142,758 & 400,102 & &, 357 &, 724 \\
& AVIT &,- 490 & 2,197 &,- 611 &,- 223 &, 826 \\
& ATET &, 476 & 2,714 &, 860 &, 175 &, 862 \\
& ITM & $-1,989$ & 9,025 &,- 832 &,- 220 &, 827 \\
\hline
\end{tabular}

a. Dependent Variable: $\mathrm{VO}_{2}$ BEEP

Based on the regression analysis (Table 2), it is noticeable that the connection of morphology measures with the result of the maximum oxygen consumption achieved on the Beep test $\left(\mathrm{VO}_{2} \max \right)$ is $\mathrm{r}=0.231$ or $23 \%$, while the rest of $77 \%$ is unexplained or influenced by other factors. When the analysis of the prediction of the results of the maximum oxygen consumption for the Beep test, that was based on the variable for the assessment of morphological characteristics (Table 3) was completed, it was visible that a statistically significant prediction about the results of maximal oxygen consumption on the Beep test (based on the applied variables for the assessment of morphological characteristics) was not determined.

Table 4. Regression analysis of the Beep test and variables used for the evaluation of morphological characteristics

\begin{tabular}{lcccc}
\hline Model & $\mathrm{R}$ & R Square & $\begin{array}{c}\text { Adjusted R } \\
\text { Square }\end{array}$ & Std. Error \\
\hline 1 &, $225^{\mathrm{a}}$ &, 051 &,- 073 & 286,636 \\
\hline
\end{tabular}

a. $\quad$ Predictors (Constans) AVIT, ATET, ITM

b. Dependent varijable BEEP

Tabela 5. Results of the Beep test (meters crossed) based on morphological characteristics

\begin{tabular}{|c|c|c|c|c|c|c|}
\hline & \multirow[t]{2}{*}{ Model } & \multicolumn{2}{|c|}{ Unstandardized Coefficients } & \multirow{2}{*}{$\begin{array}{c}\text { Standardized } \\
\text { Coefficients } \\
\text { Beta } \\
\end{array}$} & \multirow[t]{2}{*}{$\mathrm{t}$} & \multirow[t]{2}{*}{ Sig. } \\
\hline & & $\mathrm{B}$ & Std. Error & & & \\
\hline \multirow{4}{*}{1} & (Constant) & 7849,050 & 24708,714 & & ,318 & ,754 \\
\hline & AVIT & $-32,127$ & 135,673 &,- 650 &,- 237 &, 815 \\
\hline & ATET & 31,783 & 167,615 & ,931 & , 190 &, 851 \\
\hline & ITM & $-129,790$ & 557,367 &,- 880 &,- 233 &, 818 \\
\hline
\end{tabular}

a. Dependent Variable: BEEP

After analyzing the results of the regression analysis (Tables 4 and 5), it was observed that the correlation of morphological characteristics with the result achieved on the Beep test (meters crossed) is $r=0.225$ or $22.5 \%$, while the rest of $77.5 \%$ remained unexplained or under the influence of other factors. When the analysis of the prediction of the Beep test results (meters crossed) based on variables for estimating morphological characteristics was conducted, a 
statistically significant prediction of the Beep test result (meters crossed) based on the applied variables for estimating morphological characteristics was not determined.

Table 6. Correlation of the predictor variables with the results of the Beep test $\left(\mathrm{VO}_{2}\right.$ mac and meters crossed)

\begin{tabular}{|c|c|c|c|c|}
\hline \multirow{2}{*}{ BEEP } & \multirow{2}{*}{ Pearson Correlation } & AVIT & ATET & ITM \\
\hline & &,- 150 &,- 220 &,- 179 \\
\hline \multirow{3}{*}{ VO2 BEEP } & $\begin{array}{c}\text { Sig. (2-tailed) } \\
\text { N }\end{array}$ & $\begin{array}{l}456 \\
27\end{array}$ & $\begin{array}{c}271 \\
27\end{array}$ & $\begin{array}{l}, 371 \\
27\end{array}$ \\
\hline & Pearson Correlation &,- 151 &,- 226 &,- 187 \\
\hline & $\begin{array}{c}\text { Sig. (2-tailed) } \\
\text { N }\end{array}$ & $\begin{array}{c}, 451 \\
27\end{array}$ & $\begin{array}{c}, 256 \\
27\end{array}$ & $\begin{array}{c}, 351 \\
27\end{array}$ \\
\hline
\end{tabular}

$\mathrm{BEEP}$ - beep test, $\mathrm{VO}_{2} \mathrm{BEEP}$ - maximum oxygen consumption on the beep test

Based on the results of the correlation analysis (Table 6), it is clear that there is no statistically significant association of variables for estimating morphological characteristics with the result achieved on the Beep test and the maximum consumption of oxygen on the Beep test.

Table 7. Descriptive statistics of the Cooper test and variables used for the assessment of morphological characteristics

\begin{tabular}{ccccccc}
\hline Variables & N & Min & Max & Mean & S D & KS test \\
\hline AVIT & 27 & 170,00 & 193,00 & 183,11 & 5,12 & 0,856 \\
ATET & 27 & 60,00 & 89,00 & 81,25 & 8,02 & 0,992 \\
ITM & 27 & 18,87 & 26,26 & 22,59 & 1,96 & 0,999 \\
KUPER & 27 & 2550 & 3100 & 2761,85 & 152,59 & 0,582 \\
VO2 KUPER & 27 & 45,40 & 57,60 & 50,10 & 3,38 & 0,563 \\
\hline
\end{tabular}

Legend: N - number of examinees; Min. - minimal result; Max. - maximum result; Mean - arithmetic mean; Std. Deviation - standard deviation; KS (p) - value of probability of Kolmogorov-Smirnov test; AVIT - body height, ATET - body weight, ITM - body mass index, $\mathrm{VO}_{2}$ KUPER - maximum oxygen consumption achieved on the Cooper test; KUPER - number of meters of running earned on the Cooper test.

Table 7 shows the descriptive values of the variables used for estimating morphological characteristics and variables used for estimating the maximum oxygen consumption and the results of the number of meters of running earned on the Cooper test. It was observed that the most part of distribution of results is fairly well grouped and that there are no significant deviations from the mean values of the results. The results distribution scores for the applied variables were tested using the Kolmogorov - Smyrnov test, and it is obvious that the obtained values were significantly above 0.00 , which indicates that the hypothesis about the normal distribution of results should be accepted. After analyzing the results of the Cooper test, it is obvious that the highest score achieved by the examinees was 3,100 meters and the minimum score was 2,550 meters, with a range of 550 meters between the minimum and the maximum score. Analysis of the maximum oxygen consumption at the Cooper test shows that examinees achieved a maximum value of $57.60(\mathrm{ml} / \mathrm{kg} / \mathrm{min})$ and a minimum of $45.40(\mathrm{ml} / \mathrm{kg} / \mathrm{min})$ with a range of $12.2(\mathrm{ml} / \mathrm{kg} / \mathrm{Min})$. 
Table 8. Regression analysis of maximum oxygen consumption at the Cooper test and variables used for estimating morphological characteristics

\begin{tabular}{lcccc}
\hline Model & $\mathrm{R}$ & R Square & $\begin{array}{c}\text { Adjusted R } \\
\text { Square }\end{array}$ & Std. Error \\
\hline 1 &, $288^{\mathrm{a}}$ &, 083 &,- 037 & 3,44911 \\
\hline
\end{tabular}

a. $\quad$ Predictors (Constans) AVIT, ATET, ITM

b. Dependent varijable VO2 KUPER

Table 9. The results of maximum oxygen consumption on the Copper test based on variables used for estimating morphological characteristics

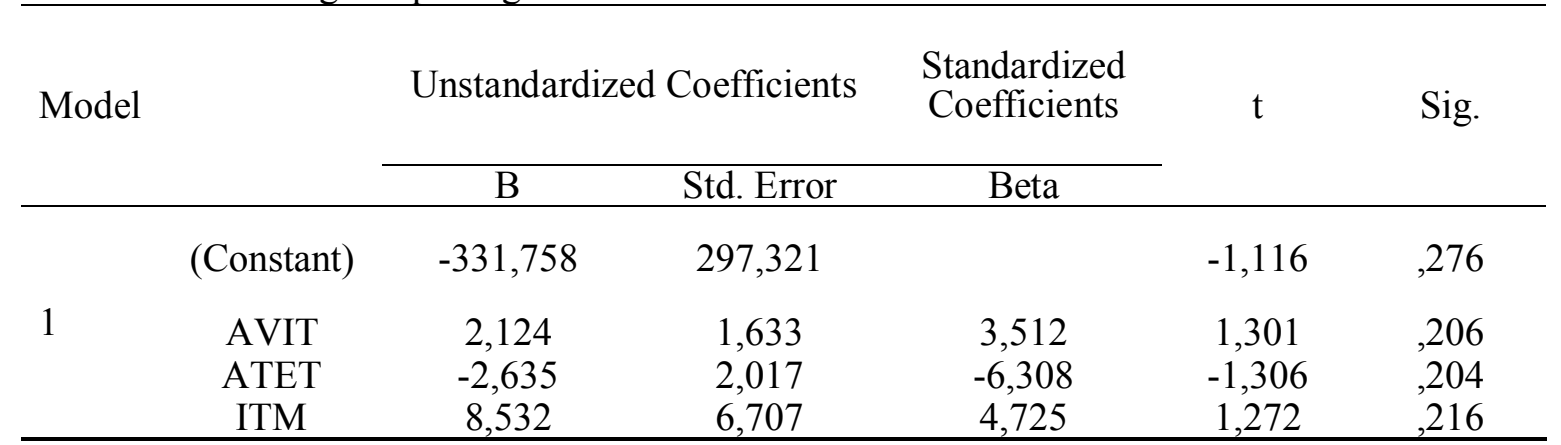

a. Dependent Variable: $\mathrm{VO}_{2}$ KUPER

Based on the results of the regression analysis (Table 8), it was concluded that the correlation between the variables for estimating morphological characteristics and the result of the maximum oxygen consumption achieved on the Cooper test is $r=0.288$ or $28.8 \%$, while the rest of $71.2 \%$ is unclear or influenced by other factors. After the analysis of the prediction of the results of the maximum oxygen consumption at the Cooper test based on the variables for the assessment of morphological characteristics (Table 9), it was concluded that a statistically significant prediction of the results of maximum oxygen consumption at the Cooper test (based on the variables used for the evaluation of morphological characteristics) was not determined.

Table 10. The regression analysis of the Cooper test and variables used for the evaluation of morphological characteristics

\begin{tabular}{lcccc}
\hline Model & $\mathrm{R}$ & R Square & $\begin{array}{c}\text { Adjusted R } \\
\text { Square }\end{array}$ & Std. Erro \\
\hline 1 &, $289^{\mathrm{a}}$ &, 084 &,- 036 & 155,294 \\
\hline
\end{tabular}

a. $\quad$ Predictors (Constans) AVIT, ATET, ITM

b. Dependent varijable KUPER 
Table 11. Results of the Cooper test (meters crossed) based on the variables used for the evaluation of morphological characteristics

\begin{tabular}{ccccccc}
\hline \multirow{2}{*}{ Model } & & \multicolumn{2}{c}{ Unstandardized Coefficients } & $\begin{array}{c}\text { Standardized } \\
\text { Coefficients }\end{array}$ & t & Sig. \\
\cline { 3 - 5 } & & B & Std. Error & Beta & & \\
\hline \multirow{2}{*}{1} & (Constant) & $-14570,704$ & 13386,688 & & $-1,088$ &, 288 \\
& AVIT & 96,407 & 73,505 & 3,539 & 1,312 &, 203 \\
& ATET & $-119,541$ & 90,811 & $-6,352$ & $-1,316$ &, 201 \\
& ITM & 387,066 & 301,970 & 4,758 & 1,282 &, 213 \\
\hline
\end{tabular}

a. Dependent Variable: KUPER

After analyzing the results of the regression analysis (Table 10), it was obvious that the correlation of the variables used for estimating morphological characteristics with the result achieved on the Cooper test (meters crossed) is $r=0.289$ or $28.9 \%$, while the rest of $71.1 \%$ is unexplained or influenced by other factors. After the analysis of the prediction of the results of the Cooper test (Table 11) based on the variables used for the assessment of morphological characteristics, it was concluded that there was not statistically significant prediction of the results of the Cooper test based on variables used for assessing morphological characteristics.

Table 12. Correlation of the variables used for the evaluation of the morphological characteristics and the results of the Cooper test

\begin{tabular}{lcccc}
\hline \multirow{2}{*}{ KUPER } & AVIT & ATET & ITM \\
\cline { 3 - 5 } & Pearson Correlation &,- 017 &,- 114 &,- 122 \\
& Sig. (2-tailed) &, 933 &, 573 &, 546 \\
NO2 KUPER & 27 & 27 & 27 \\
\cline { 2 - 5 } & Pearson Correlation &,- 018 &,- 114 &,- 121 \\
& Sig. (2-tailed) &, 927 &, 571 &, 548 \\
N & 27 & 27 & 27 \\
\hline
\end{tabular}

The analysis of the correlation shows that there is not any statistically significant correlation of morphological characteristics with the result achieved at the Cooper test $\left(\mathrm{VO}_{2} \max \right.$ and meters crossed). Previous analyzes also show that these characteristics do not have a statistically significant correlation with the results obtained on the Beep test and the Cooper test.

Table 13. Correlation of the results of the Cooper (KUPER) test with the results of the Beep test

\begin{tabular}{lccc}
\hline \multirow{2}{*}{ BEEP } & Pearson Correlation & KUPER & $\mathrm{VO}_{2}$ KUPER \\
\cline { 3 - 4 } & Sig. (2-tailed) &, 645 &, 736 \\
$\mathrm{~N}$ &, 000 &, 000 \\
$\mathrm{VO}_{2}$ BEEP & 27 & 27 \\
\cline { 2 - 4 } & Pearson Correlation &, 688 &, 712 \\
& Sig. (2-tailed) &, 000 &, 000 \\
$\mathrm{~N}$ & 27 & 27 \\
\hline
\end{tabular}


Table 13 shows that a high correlation between the Beep test and the Cooper test was obtained and it shows maximum oxygen consumption achieved on the Beep test and the Cooper test. It also shows that there was high correlation between the Beep test and the maximum oxygen consumption at the Cooper test, and the maximum oxygen consumption achieved on the Beep test and the maximum oxygen consumption achieved on the Cooper test. These results indicate that it is possible to use one test instead of the other, depending on the testing conditions and the requirements.

\section{DISCUSSION}

Based on the value of the results of the anthropometric characteristics of the students shown in Table 1, we can conclude that the average height of the sample of $183.11 \mathrm{~cm}$ along with the body mass of $81.25 \mathrm{~kg}$ indicates the normal body mass index (22.59) of the study sample. Considering the fact that the sample of the study were students who were subjected to the selection process during the process of enrollment to faculty, we can consider that these values define the normal body mass and are turned to a non-fat component with a far greater percentage of muscle mass than the subcutaneous fat tissue. The values of the central and dispersion parameters for evaluation of the results achieved on the Beep test and the maximum oxigen consumption during the performance of the Beep test show a normal distribution and are indicators of the current physical capability of the students of the Faculty of Security Sciences. The results shown in Tables 2 and 3 are proof that there is no statistically significant qualitative correlation between predictor and criterion variables, which results in the impossibility of predicting the results of maximum oxygen consumption at the Beep test based on the applied variables used for estimating morphological characteristics. Almost identical results were shown in Tables 4 and 5, with the results achieved on the Beep test and the possibility of predicting the results achieved based on variables used for estimating morphological characteristics. After comparing the mean value of the results our students' obtained on the Beep test to the predicted mean values of the results of Australian police services who use the Beep test to check the functional abilities of their officers (South Australia Police 9.04, Air Service Australia 9.60, Royal Air Force 9.10, Western Australia Police 10.1, British Army 10.2 and Royal Marines 13.00), we found that the results of our students are below the predicted average, which indicates that the functional capabilities of our students assumed for the successful performance of official tasks are not at a satisfactory level, while comparison of the mean value of the results of the maximum oxygen consumption of our students achieved on the Beep test with the mean values of the results predicted for that age shows that our students achieved an average result, and, based on that, we can conclude that the aerobic-anaerobic abilities of our students are at an average level. Table 6 shows the results of the correlation analysis of the obtained results and the results of the maximum oxygen consumption on the Beep test with variables used for estimating morphological characteristics. Relatively low level of correlation coefficients confirms the match of the results of the regression analysis of the criteria in the current prediction space. The values of the Pirson correlation coefficient show that the highest correlation between the achieved result (poor negative correlation) and the results of the maximum oxygen consumption on the Beep test was obtained with the variable of weight, which indicates that subjects with lower body weight achieved better results and, therefore, a higher level of maximum oxygen consumption. However, although this study did not show that longitudinal dimensionality affects the results of tests used for estimating maximum oxygen consumption, some previous researches gave certain results related to this problem. According to Jakovljević, Ljubojević, Karalić, Gerdijan \& Vukić (2014), the influence of anthropometric characteristics on the conditional parameters of the footballers was researched (Wong, Chamari, Dellal \& Wisloff, 2009), which proved that there was a statistically significant correlation between body height and the results on the Beep test ( $p$ $=0,26)$, as well as between body height and maximum oxygen consumption on the Beep test ( $\mathrm{p}$ 
$=0.35)$. The results of the correlation between the variables used for the evaluation of morphological characteristics and the results obtained at the Cooper test and the results of the correlation between the variables used for estimating the morphological characteristics with the maximum oxygen consumption at the Cooper test are shown in Tables 7, 8, 9, 10 and 11. The same as with the previous results, we can conclude that there is no statistically significant correlation between the predictor and the criterion variables, which also results in the impossibility of predicting the results achieved on the Cooper test and the results of the maximum oxygen consumption on the Cooper test. These results can be explained by the fact that this is a selected sample of subjects whose morphological characteristics values move within the normal distribution. It should be mentioned that Mitrovic and his associates (2015) conducted a survey in which they examined the correlation between the state of physical nutrition and the level of aerobic fitness of members of special police units. The authors had a sample of 72 male examinees of the average age of $34.2 \pm 5.2$ years, an average working life of $12.5 \pm 4.9$ years and an average body mass index of $27.59 \mathrm{~kg} / \mathrm{m} 2$, examining the correlation between the body mass index and maximum running at 3000 meters as one of the variants of the Cooper test. The conclusion of the research was that there are statistically significant differences between selected and trained police officers between the state of nutrition and the speed of running in the aerobic energy strain regime, in the opposite proportional direction. This correlation is explained at the level of $33.4 \%$ of the total variance, which leads to the conclusion that a higher level of body nutrition indicates a statistically significant level of aerobic performance. The results of the correlation analysis of the obtained results and the results of the maximum oxygen consumption at the Cooper test with variables used for estimating the morphological characteristics are shown in Table 12. Based on Pirson's coefficient of correlation, obtained results are almost identical as in Table 6 . If we compare the results of our students with the values that are expected by the criteria for the same age on the Cooper test, we can see that the state of competence of our students is good. In order to have a more complete picture of the functional abilities of our students, it is necessary to go through the studies of the abilities listed above that were conducted on a similar sample of examinees. If we compare mean values of the results of our respondents achieved on the Cooper test with the average values of the results achieved by students of the eleventh generation of the The Academy of Criminalistic and Police studies from Belgrade (Blagojević, Dopsaj \& Vučković 2006), we can see that the results our students achieved are approximate to the results of the students of the eleventh generation of The Academy of Criminalistic and Police studies from Belgrade. Table 13 shows the correlation of the results of the Beep test and the Cooper test and the correlation of the results of the Beep test with the maximum oxygen consumption at the Cooper test. The table shows that there is a very high correlation between the results of the Beep test with the results of the Cooper test and the maximum oxygen consumption at the Cooper test, as well as that there is a very high correlation between the maximum oxygen consumption on the Beep test with the results of the Cooper test and the maximum oxygen consumption at the Cooper test.

For efforts that last longer period of time, the main determining factor is not only the maximum oxygen consumption that the respondent can achieve on testing, but it is also very important to determine on which level the maximum aerobic capacity can be used. The higher the level of training is, the greater is the percentage of possible aerobic capacity utilization, which indicates that the examinee who is able to execute oxygen consumption at a higher level will be more capable. In the Cooper test, motivation has an extremely important role and is one very important factor of success. We simply can not ignore the fact that the test is relatively strenuous and long lasting, so objective indicators of the condition can only be expected with highly motivated individuals. It should also be stressed that the Cooper test is, practically, possible to run only on the athletic track, because in other measured areas the examinees get so far apart that, after a few minutes, the examiner is not able to track all the examees and record their score after a 12-minute period expires. The Beep test is one of the most popular test procedures that is currently used in the assessment of aerobic endurance (Leger \& Boucher, 
1980; Leger \& Lambert, 1982; Leger, Mercier, Gadoury, \& Lambert, 1988). Because of the fact that the test is performed in a way that the speed of the run is defined by the sound signal coming from a $\mathrm{CD}$, computer or other audio output, it is impossible to achieve the wrong result on the Beep test, due to the excessive running intensity or the underestimation of your own abilities. The test is normally performed indoors, but it can also be performed in an open space. However, precisely this feature (that the Beep test can be performed indoors) is a significant comparative advantage over other aerobic endurance tests. The biggest advantage of this test is the fact that it is possible to test a larger group of examinees in a small area at the same time, where the experience of the examinee has no impact on the test, while minimal changes in running speed enable examinees to estimate the required intensity of work very precisely. Even though most of the SFO program content is taking place under anaerobic conditions (movements are performed in the shortest time unit possible), we should not forget the possibility of performing such motor programs that require more time, and (due to that fact) other conditions (aerobic - Anaerobic) in which motor programs will be realized. This, of course, involves activity in which there is increased oxygen consumption and it mainly depends on the energy capacity of the organism, which should provide sufficient repetition of specific motor programs. High level of energy capacities gives the opportunity not only for long-term work and development of specific motor programs from the SFO, but also the possibility of their practical usage. Therefore, if we want our students to fully accept specific motor programs and the possibility of their practical usage, they must have appropriate energy abilities in the process of learning and improvement, which would enable them both optimal work intensity and optimal number of repetitions. Obtained informations can be used to make and optimize the SFO plan and program, while creating homogeneous groups in the classroom, which would ensure continououity of learning and improvement, as well as in the selection of candidates for enrollment at the FSS.

\section{CONCLUSION}

The research was conducted in order to determine the influence of morphological characteristics on the results of the Beep test and the Cooper test and the maximum oxygen consumption on the Beep test and Cooper test, in order to confirm the influence of the defined variables as justified variables in the diagnostic field tests, and to observe the state of the functional students' abilities on the basis of the value of the Beep test and Cooper test, but also the maximum consumption of oxygen on the Beep test and Cooper test. After the obtained results and their processing by the appropriate statistical procedure, it was concluded that there is no statistically significant association of variables used for the evaluation of morphological characteristics with the results achieved on the Beep test and Cooper test, and that there is no statistically significant connection of the variables used for the evaluation of morphological characteristics with the results of maximum oxygen consumption on the Beep test and Cooper test. Furthermore, it was determined that there is no a difference in the maximum oxygen consumption between the tests that were applied, which can be explained by the specific characteristics of the applied tests. Based on the results obtained after this research and due to the characteristics of the Beep test and the Cooper test, as well as due to the possiblity of measuring them in different conditions, the authors suggest that the functional capabilities of the candidates in the process of selecting candidates for admission to the Faculty of Security Sciences should be tested by the Beep test. Having this in mind, it is necessary to have another (similar) research to determine, with more precise measurements, how long and in what operating mode each individual can be efficient, not only in acquiring teaching contents, but also for programming and controlling training procedures in the field of SFO. 


\section{REFERENCES}

Beep test VO2max calculator. (20.01.2014.).Topend sport \& Science resource. Retrieved (20.01.2014) from http://www.topendsports. com/testing/beepcalc.htm

Blagojević, M., Vučković, G. \& Dopsaj, M. (2006). Specijalno fizičko obrazovanje 1 - osnovni nivo, Kriminalističko policijska akademija, Beograd, RS.

Blagojević, M., Vučković, G. \& Dopsaj, M. (2016). Specijalno fizičko obrazovanje 2 -usmjereni nivo, Kriminalističko policijska akademija, Beograd, RS.

Jakovljević V., Ljubojević A., Karalić T., Gerdijan N. \& Vukić Ž. (2014). Relacije morfoloških karakteristika i maksimalne potrošnje kiseonika učenika četvrtog razreda osnovne škole u odnosu na pol. Fizička kultura, 68(1), 63-74.

Léger L. \& Boucher R. (1980). An indirect continuous running multistage field test: the Université de Montréal track test. Can J Appl Sport Sci. 5(2), 77-84. PMid: 7389053

Leger, L.A. \& Lambert, J. (1982). A maximal multistage $20 \mathrm{~m}$ shuttle run test to predict VO2max, European Journal of Applied Physiology, 49, 1-5. https://doi.org/10.1007/BF00428958

Leger, L., Mercier D, Gadoury C. \& Lambert J. (1988). The multistage 20 metre shuttle run test for aerobic fitness. J Sports Sci. Summer, 6(2), 93-101.

https://doi.org/10.1080/02640418808729800 PMid:3184250

Leger, L. \& Gadoury, C. (1989). Validity of the $20 \mathrm{~m}$ shuttle run test with 1 minute stages to predict VO2max in adults. Canadian Journal of Sport Science, 14(1), 21-26 PMid:2924218

Matković, B. \& Ružić, L. (2009). Energija za rad. U: B. Matković i L. Ružić (ur.), Fiziologija sporta $i$ vježbanja, (pp 37-51). Zagreb, RH: Odjel za izobrazbu trenera Društvenog veleučilišta u Zagrebu; Kineziološki fakultet Sveučilišta u Zagrebu.

Milošević, M. \& Milošević, M. (2013). Specijalno fizičko obrazovanje - Naučne osnove, Beograd, RS: CEDIP.

Naughton, L.M., Cooley, D., Kemey, V., \& Smith,S. (1996). A comparision of two diff erent shuttle run test for the estimation of VO2 max. The Journal of Sports Medicine and Physical Fitness, 36 (2), 85-89. PMid: 8898512

Pavlović, R., Savić, V. \& Tošić, J. (2012). Uticaj morfoloških, motoričkih i funkcionalnih parametara u procjeni fitness indexa i maksimalne potrošnje kiseonika. Sport i zdravlje VII, $30-37$.

Pelemiš, V., Mitrović, N., Cicović, B. \& Lolić, D. (2011). Maksimalna potrošnja kiseonika kod različitih grupa sportista. Sportske nauke i zdravlje 1(1), 52 - 57.

Ramsbottom et al. (1988). A progressive shuttle run test to estimate maximal oxygen uptake. British Journal of Sports Medicine, 22, 141-145. https://doi.org/10.1136/bjsm.22.4.141

PMid:3228681 PMCid:PMC1478728

Skinner, J. S., \& McLellan, T. H. (1980). The transition from aerobic to anaerobic metabolism. Research Quarterly Exercise and Sport, 51, 234-248. https://doi.org/10.1080/02701367.1980.10609285 PMid: 7394286

Sudarov, N. (2007). Testovi za procenu fizičkih performansi. Novi Sad, RS. Pokrajinski zavod za sport.

Vučič, J. (2016). Procena maksimalne potrošnje kiseonika pomoću gasnog analizatora i trake za trčanje kao mera aerobne sposobnosti sportiste. Diplomski rad. Prirodno matematički fakultet Univerziteta u Novom Sadu. 
Wong, P.L., Chamari, K., Dellal, A., \& Wislőff , U. (2009). Relationship between anthropometric and physiological characteristics in youth soccer players. The Journal of Strength and Conditioning Research, 23(4), 1204-1210.

https://doi.org/10.1519/JSC.0b013e31819f1 e52

PMid: 19528844

Received: 06.05.2017.

Accepted: 26.06.2017.

Correspondence author:

DarkoPaspalj,PhD

Faculty of Security Sciencess, University of Banja Luka

Bulevar vojvode Živojina Mišića 10 a,

78000 Banja Luka

Bosnia i Herzegovina

Tel:+38751333603

+38765906325

dpaspalj@yahoo.com 